\title{
Introduction
}

MICHAEL RUSE

\section{Biographical background}

Thomas Henry Huxley was born in 1825, in the village of Ealing (close to London), the second son of a schoolmaster. His was not a very happy childhood. His mother lacked warmth, and his father was soon unemployed and sinking into a depressive madness that was to plague Huxley himself throughout his life. Yet, from the first there was mettle and talent abundant in the child, as he became a voracious reader and selfeducator. In his teens, Huxley was apprenticed to medical practitioners, finally becoming a scholarship student at the Charing Cross Hospital. A brilliant career-Huxley won a gold medal for his studies in anatomy and physiology — was cut short by a desperate need for funds, and so at the age of twenty he joined the Royal Navy as an assistant surgeon, a far less prestigious post than the title would seem to suggest. (He was truly just the real surgeon's mate.)

Huxley was assigned to HMS Rattlesnake and spent the years $184^{6}$ to $185^{\circ}$ traveling the South Seas, including a lengthy visit to Australia, where he met the young woman who was to become his wife (J. S. Huxley 1935). Since Huxley was to entwine his fate with that of Charles Darwin, the great English scientist rightly known as the father of evolutionary theory for his work On the Origin of Species (1859), it is interesting and productive to compare the two men briefly. There 
are patterns of similarity. The decade before, Darwin had spent several years $\left(183^{1-1} 8_{3} 6\right)$ on a British warship, HMS Beagle, as it sailed the Southern Hemisphere, mapping the coast of South America before it circled the globe, crossing the Pacific to Australasia and thence home (Darwin 1839). However the differences are far greater. Huxley was middle class, but barely. On the Rattlesnake he messed with the midshipmen, the officers in training. Darwin was from a very rich family-his maternal grandfather (shared by his wife-to-be, Emma) was Josiah Wedgwood, the founder of the English pottery trade and a very successful capitalist. Darwin was a paying guest on the Beagle and messed with the captain. More significant was the fact that Darwin was a naturalist through and through. It was the diversity of life, in its geographical (or, for fossils, geological) setting, that excited him. He became an evolutionist because he was so inspired by the geographical distributions of the denizens (the tortoises and the birds) of the Galápagos Archipelago in the Pacific. Huxley cared little for natural history. He was an anatomist through and through. On the Rattlesnake he laid the foundation of his career as he dissected the fragile, marine invertebrates (jellyfish and the like) that the nets of the ship brought up each morning. For him, the excitement was the structural form of the animals, tracing their pasts and relationships, and comparing one species with another (T. H. Huxley 1898). A dead animal was a good animal from his perspective.

Returning to England, T. H. Huxley's talent was now being recognized by the scientific fraternity. Fel- 
lowship in the Royal Society soon came his way, as did growing friendship with some of the men who were to define later Victorian science, notably the physicist John Tyndall and the botanist Joseph Hooker. By the middle of the $185 \mathrm{os}$, Huxley found permanent employment in the London higher-educational establishment (first the School of Mines) and-despite pleas from England's old universities-he was never to leave the nation's capital. Eventually, he became dean of the science college in South Kensington, an establishment founded on the profits of the Great Exhibition of $185^{1}$ and today known as Imperial College. Huxley also served on various royal commissions, for several years being an inspector of fisheries (a major industry in the British island), and in science organizations, becoming the president of the British Association for the Advancement of Science as well as the Royal Society. He was not the type of man who could have accepted an establishment honor like a knighthood, but he was deeply gratified when, at the end of his life, he was made a privy councilor. This is a somewhat honorific post of people who are supposed to advise the monarch. Because technically it does require work, Huxley felt he could accept it. He joked, but he did rather like the fancy Gilbert-and-Sullivan-type uniform that went with it.

\section{Evolution}

Throughout his scientific career, Huxley kept up a high rate of productivity, in anatomy and then increasingly in paleontology. Four hefty volumes of his Scien- 
tific Memoirs, plus a supplement, were published (18981903). One senses, however, that he was more brilliant than creative and that his work was good but not pathbreaking. More important to science was the huge effort he made and legacy he left as an educator, teaching large numbers of students and writing influential textbooks. He was concerned not just about higher education, but about secondary education as well. He sat on the London School Board and also made major efforts to improve the quality of high-school science teaching. One young man who came under his sway was the future novelist H. G. Wells. Stories and novels such as The Time Machine show fully the influence of the teacher.

Important though this work may have been, Huxley is far better known-both then and today-for his advocacy of evolution. Mythical is the way in which he engaged opponents of the idea, most notably Samuel Wilberforce, bishop of Oxford (and son of the great opponent of slavery William Wilberforce), at the meeting of the British Association at Oxford in 1860. Supposedly, the bishop asked the professor if he was descended from a monkey on his grandfather's side or his grandmother's side, to which the professor replied that he would rather be descended from a monkey than from a bishop. This story is most certainly apocryphal-the two men did clash, and there probably was some testy exchange (with Huxley saying he would rather be descended from an ape than from a man of talent who failed to use it in the search for truth), but whether they quite caused the immediate sensation of lore is doubtful (Lucas 1979). However, like Moses 
and the Pharaoh, it is the meaning and symbolism that counts. In telling and retelling the tale, the victory of science grew and grew, and the pathetic response of religion was ever more deeply confirmed.

Almost paradoxically, when Huxley was first made to think seriously about evolution-in a review he wrote of a popular evolutionary tract, The Vestiges of the Natural History of Creation, in the early $1850 \mathrm{os}$-he was strongly against the idea. He quoted Macbeth, quipping "time was when the brains were out the man died" (T. H. Huxley 1903, 425). Huxley thought evolution had little basis in fact and, more than this, was a sloppy notion that upset his somewhat puritanical standards about the moral worth of doing good science. But then Huxley met Darwin and it is clear that, like many, he fell beneath the spell of the older man's enthusiasms and genuine warmth. Like Saint Paul many years before him, likewise the initial denier of a great idea he was to champion for the rest of his life (actually the popular press likened Huxley more to Saint Peter, referring to him as "Pope Huxley"), Huxley swung from being an opponent to being the greatest enthusiast and booster. For nearly forty years, Huxley lectured nonstop on things evolutionary, and essay after essay poured forth from his active pen. His energy and efforts on behalf of the idea of evolution were formidable beyond the point of being awe inspiring.

And yet, here we encounter a conundrum that leads toward the essay reprinted in this volume. Although his bond with Darwin was deep and lasting-Darwin was frequently sick and one senses that Huxley felt 
himself a younger brother who could defend the needy family member-and although his commitment to evolution was absolute, it was not at all what or how one might expect. On the one hand, Huxley was indifferent to ideas that Darwin thought absolutely central. The aim of the Origin is more than simply that of establishing the fact of evolution. Darwin promoted his causal hypothesis of natural selection. Organisms adapt and this comes about through a struggle for existence (and reproduction), leading to the triumph of those forms that have features that help their owners to succeed in the battle. Huxley, the anatomist, cared little about adaptation-a dead organism needs no help to survive-and even less about natural selection as a universal mechanism. He was far from rejecting it, but it was not, as it was for Darwin, the key player in the game. He was more interested in similarities and differences, lineages and connections. On the other hand, as an educator Huxley had little time for evolution. This sounds incredible, but it is true. For years, he would give an absolutely massive series of lectures on anatomy. There would be hardly a word on evolution and less on natural selection. In the Huxley $\mathrm{Pa}-$ pers (hereafter, HP), there are the notebooks of one W. W. Cobb, who attended Huxley's lectures in 187475. These notebooks are incredibly detailed, with copious drawings. (Huxley was a great blackboard artist, a real boon in the pre-PowerPoint days.) Consider the passage dealing with classification:

About 2o years ago [1854] Prof. Huxley was inclined to think that the various groups of animals 
did exhibit a sharply-defined line of separation; and that the more the so-called transitional forms were examined into, the more his opinion would be confirmed. But when at that time he expressed this opinion to Mr. Darwin, the latter replied, that his own researches and observations led him to exactly the opposite conclusion: and it is certain that every recent inquiry has tended to break down the lines of demarcation between diff. groups. (HP 69.5)

You would think that the man who was known as "Darwin's Bulldog" would take this as the perfect opportunity to launch into a peon of praise for evolution. Not a bit of it! The lectures go straight on to the invertebrates, whose guts are pinned out across the dissection table. The reasons behind Mr. Darwin's "researches and observations" go unmentioned.

\section{The secular religion}

Why the silence? The major reason is that evolution did not fit into Huxley's plans as a science educator. Ask any university administrator-and Huxley was nothing if not this-and the key behind any successful enterprise is cold, hard cash. If you want to put on a course or a program, the first question is about payment. Who is going to support the lecturer and who is going to pay for the buildings and their upkeep? In Huxley's case, answering this question gives both cause and effect. The period from the late $185^{\text {os }}$ to the early 186 os, the time when Huxley was really get- 
ting into his stride as a teacher, was the point when Great Britain faced a crisis. After the appalling conditions of the Crimean War, in which more soldiers died away from the fighting than on the battlefields; after the deeply upsetting events in India, when the sepoys (the native soldiers) had mutinied and been put down only with great effort and violence; after the "Great Stink" of 1858 , when the Thames literally became a cesspool and the inhabitants of London had to flee the smells and filth of their major waterway, it was clear that there was much need of the functioning apparatus of a modern state. There was need of a properly trained military, of a qualified civil service, of medics who cured rather than killed, of civil and other engineers who may not know much Latin and Greek but who could use logarithms when needed, and of much, much more. Huxley and his friends and supporters-remember Florence Nightingale, the "lady with the lamp," who was at the head of reforming the nursing profession-set about remedying the situation. Hence the work on science education and hence the market for his students and hence the needed support. Physiology was something sold to the medical profession. Huxley and his associates would train young men (no women at this point) in the science, and then the students could go on to clinical training and become doctors. Anatomy was something for the schoolroom. Teachers could give anatomy courses and thus train children in the arts of observation and hands-on preparation. Huxley and his associates were providing the educators with the needed knowledge and skills. 
Where did evolution fit into all of this? It simply got excluded. It did not cure a pain in the belly, and even Huxley realized that it was a bit risqué for the classroom. Hence, the silence in Huxley's science training. But then, what was Huxley doing lecturing and writing nonstop on evolution? With some reason, he saw the Christianity of the day, especially the Christianity of the establishment, the Church of England, as supporting the old ways of doing things, with little interest in reforming society and its ways. Hence, for Huxley, the fight with people like the bishop of Oxford was as much social and cultural as it was theological. Huxley also realized that if he were to be successful in this fight, he needed a substitute, a kind of secular religion. Evolution provided this! It was a story of origins that made humankind central and that offered moral prescriptions-all of the sorts of functions one finds in a good religion.

This may sound strange. In the Origin of Species, Charles Darwin affirmed explicitly that humans are part of the evolutionary picture, but in that book, at least, he gave us no special role. Moreover the Origin was a book of science about the ways that things are or were. It tells us nothing about the ways that things should be. However, although Darwin's name was always being promoted, his omissions (if such they be) were of no great moment, for he was not the crucial figure in the story. Here we must introduce one of the most remarkable figures of the nineteenth century, Herbert Spencer-Englishman, evolutionist, sociologist, philosopher, neurotic bachelor, and a man with a worldwide influence. Spencer, born in the British Mid- 
lands, broke into the public domain in the 185 os with a series of books and articles promoting theories of economics, evolution (he went public on this nearly a decade before Darwin), and, above all, the philosophy of progress. He saw everything-the world, organisms, humans, culture, language-as being engaged in an upward march, despite barriers and vicissitudes, toward a better tomorrow. It was Spencer, a man with whom, in the early years, Huxley was incredibly friendly, who gave humans a special place in the world order, for it was he who saw our species as the apotheosis of the evolutionary process, that toward which all had been moving and which has great value above all others. It was Spencer also who saw the moral import of all of this, for the supreme principle of morality must be to cherish and encourage the evolutionary process, because it is progressive and hence tends to the good and the valuable.

Like many others, Huxley absorbed the Spencerian message, using it as a lens through which to view the (really rather different) story that was being told by Darwin-a fact, incidentally, that irritated the latter to no end when Huxley gave a series of Spencerianinfused lectures on evolution to the working classes. Evolution could be a kind of secular religion, a modern-day, science friendly substitute for outmoded Christianity. It told of where we came from, it told that we humans were the point and purpose of it all, and it gave us instructions about how we are to behave. It is little wonder that, a year or two after the Origin, Huxley sprang into print with a book on human evolution, Evidence as to Man's Place in Nature (1863). "After all, it 
is as respectable to be modified monkey as modified dirt" (Letter to F. Dyster, HP 15.106).

By any measure, Huxley's strategy-evolution-free science in the professional domain, evolution-soaked ideology in the popular domain-was incredibly successful. Britain was reformed, and turned from looking back to the eighteenth century to looking forward to the twentieth century. And as background against this, Huxley and his fellows preached the glad tidings of evolution at every possible opportunity. They even went so far as to build cathedrals for the new religion, except they did not call them "cathedrals" but "museums" of natural science or history. Instead of going to church on a Sunday morning, a family could go to "church" on a Sunday afternoon, where they would find dazzling displays of fossils - this was just the time when Americans were starting to dig up all of those fantabulous beasts of the past, from Stegosaurus, with its weird display of plates along its back, to Eohippus, the little horse that ran on five toes rather than (as do modern horses) on one-all stressing the message of progress. Monad to man, as people said.

\section{Moral questions}

What was the moral message of evolution? Most simply and obviously, it was something that took the Darwinian notion of a struggle for existence in the animal and plant world and transferred it to the human world. More commonly known as laissez-faire economics-keep the state out of people's affairs and let the forces of competitive nature take their role and im- 
prove the lot of the general public, even though some losers fall by the wayside-this would seem the perfect philosophy for the new age. Forget sentimental claptrap about loving your neighbor and prepare for the harsh but stimulating world of factories and machines. Titans of industry may make huge fortunes, but we all benefit from the work they provide and the products they produce. For losers, widows, and orphans, there is always private charity. Above all, keep the state out of the running of things, for this only encourages the second-rate and inadequate.

As it happens, the story is rather more complex than this. While it is indeed true that Spencer was an ardent supporter of laissez-faire economics, the extent to which he drew on evolutionary principles to justify this is dubious. Apart from anything else, in biology Spencer was no Darwinian. Rather than natural selection, he saw the main force of change as lying in what are known (after the early nineteenth-century French evolutionist Jean Baptiste de Lamarck) as Lamarckian factors, the inheritance of acquired characteristics. But whatever the real connections, the picture of the 1860 os was evolution, competition, progress. And Huxley was its mouthpiece. Above all, labeling himself a "scientific Calvinist," he was deeply committed to the moral worth of the natural world. In 186o, his first child, Noel, died suddenly. Although consumed by grief, in response to a letter of sympathy from the clergyman Charles Kingsley (who was soon to write The Water Babies), Huxley nevertheless responded by spelling out his philosophy of nonbelief yet of faith: 
And it is to be recollected in view of the apparent discrepancy between men's acts and their rewards that Nature is juster than we. She takes into account what a man brings with him into the world, which human justice cannot do. If I, born a bloodthirsty and savage brute, inheriting these qualities from others, kill you, my fellowmen will very justly hang me, but I shall not be visited with the horrible remorse which would be my real punishment if, my nature being higher, I had done the same thing. . . . The absolute justice of the system of things is as clear to me as any scientific fact. (L. Huxley 1900, 1, 236)

And yet anybody who knew Huxley the man, Huxley the educator, Huxley the nonstop worker to improve the ways of the state, must have realized that unquestioned subscription to a Spencerian picture of the progressive worth of the Victorian business ethic could not be a stable picture. Why on earth would Huxley promote nonstop competition, denouncing the influence of the state, when his whole life was one of working within and for the state, making Victorian Britain a better place in which to live, to work, to raise a family, to have friends? Even by the 1870 , doubts were arising and cracks appearing in the picture. This was just the point when state-supported, compulsory primary education was being introduced-pinching the Liberals' cloths, the Conservative Party had passed a reform bill enfranchising many members of the working classes, leading Prime Minister Benjamin Disraeli to comment sardonically, "now we must edu- 
cate our masters." Huxley, as a member of the London School Board, was hardly going to deny the worth of what he and his fellows were about. To the contrary, in one of his essays, "Administrative Nihilism," he wrote unambiguously, "with respect to the advancement of science and art. I have never yet had the good fortune to hear any valid reason alleged why that corporation of individuals we call the State may not do what voluntary effort fails in doing, either from want of intelligence or lack of will. And here it cannot be alleged that the action of the State is always hurtful. On the contrary, in every country in Europe, universities, public libraries, picture galleries, museums, and laboratories, have been established by the State, and have done infinite service to the intellectual and moral progress and the refinement of mankind" (T. H. Huxley 1893a, 258).

As the years went by, Huxley never deviated in the least from this conviction, adding to it only an increasing skepticism about the easy optimism of Spencer and his supporters. By the 1880s, Huxley's doubts about progress were becoming more and more pressing, leading eventually to a harsh rupture between the two old friends. There were many factors involved here. Some were public and social. People were realizing that a little science and technology was not going to solve all of society's ills. There were terrible economic downturns (known collectively as the "Great Depression," lasting from 1873 to 1896 , later to be renamed the "Long Depression," after the depression of the 1930s usurped the title) with much unemployment, city slums proved overly resistant to change and 
improvement, and the nations of the world were starting to engage in the dreadful arms races that were to lead eventually to the catastrophic conflicts of the twentieth century. Some factors were personal. Huxley's crushing bouts of depression combined with personal tragedies, overwhelmingly the illness and eventual death of a beloved daughter. How could one talk of value when bubbling life was being smudged out by fate?

It was not that Huxley wanted to deny biological progress in the sense that humans have emerged from the evolutionary process and that we are the most intelligent, the most talented, and so forth. He was quite convinced of this and that Darwinian processes (involving struggle) had brought things about. It was not that Huxley wanted to deny that there is cultural and social progress. He was, after all, a Victorian and it would have been a priori true to him that his society was as much above that of savages (as he would have regarded preliterate folk) as the heavens are above the earth. Indeed, like a good Englishman, Huxley was not above suggesting that the English are way above the French. (Many years earlier Huxley had written to a friend: "I utterly repudiate the Frenchman as a higher and a scientific man-they are logicians and not thinkers and their defects as men of science arise exactly out of their want of moral insight" [Letter to F. Dyster, HP 15.106$]$.) It was rather that Huxley wanted to deny an easy slide from the biological to the social and cultural. For Spencer, the biological and the social and cultural were one. For Huxley, the latter meant fighting against the former. 


\section{"Evolution and Ethics"}

So the scene was set for Huxley's final essay, one of the greatest pieces of writing of the nineteenth century. "Evolution and Ethics" was given as a lecture at Oxford in 1893 , and subsequently published in his Collected Essays with a prolegomena that spoke to some of the criticisms and comments that the piece had evoked. In many respects, therefore, it makes most sense to start with the main essay and then work back to the prolegomena. There is little need here to attempt a detailed summary of the arguments. Huxley's writing is clear and forceful, and makes full sense in the light of the history I have been sketching. Above all, Huxley is challenging the link between the biological and the social, the ethical. To this end, he traces the rise of moral thinking in different societies, showing how little this depends on the biological, on the evolutionary in particular.

Two groups in the past particularly interest himthe Buddhists of India and the philosophers (particularly the Stoics) of Ancient Greece. In both cases, Huxley aims to show that although the wise men realized that the world is in a state of flux, of development, true moral behavior entails curbing the beast within us. This does not mean going with nature but in some sense going against it. Huxley would not have chosen these groups idly. You might think that he would have focused rather on Jewish or Christian ethics-there is, in fact, a brief reference to Job-but he did not do so, partly because the conditions of the lecture that he was giving (sponsored by a rich Canadian, George Ro- 
manes) explicitly prohibited discussion of religion or politics, but mainly because Huxley was thinking in what he would have considered a post-Christian mode. Choosing Indian thought was a shrewd (although somewhat obvious) move, because the end of the nineteenth century was the point at which Britain's entanglement with the subcontinent was at its height. The Raj-the rule of India by the British-was simply a fact of life to everyone, and with it brought a knowledge of and interest in all things Indian, including the religions. Choosing Greek thought was no less shrewd (or obvious) because the reforms of people like Huxley had certainly not slowed the interest in the classics (particularly not at Oxford where the lecture was given) and so his listeners would have been very familiar with the ideas of which he spoke.

Then, with the historical case prepared-an interesting speculation is the extent to which the evolutionist Huxley was consciously using the past to throw light on the present-Huxley could hammer home his conclusion:

Social progress means a checking of the cosmic process at every step and the substitution for it of another, which may be called the ethical process; the end of which is not the survival of those who may happen to be the fittest, in respect of the whole of the conditions which obtain, but of those who are ethically the best. (p. 81)

The prolegomena fleshes out this thinking. By this time of his life, Huxley was retired and living in the town of Eastbourne on the South Coast of England. 
The old man was delighting in his garden, newly enclosed and now being designed and built. The metaphor that runs through this piece of writing is that of nature, wild and tamed-the South Downs (on which Huxley's house was built) as they had evolved through the forces of nature and the garden as it was planted and tended and cherished. The two are quite different, as are also the case for man in a state of nature and for man in a state of civilization. To maintain the latter against the former requires constant struggle. Although the story grows darker and darker, with no ultimate hope of future success,

[t] hat which lies before the human race is a constant struggle to maintain and improve, in opposition to the State of Nature, the State of Art of an organized polity; in which, and by which, man may develop a worthy civilization, capable of maintaining and constantly improving itself, until the evolution of our globe shall have entered so far upon its downward course that the cosmic process resumes its sway; and, once more, the State of Nature prevails over the surface of our planet. (pp. 44-45)

\section{Two questions}

Good thinking, quality thinking, is open ended. It opens as many questions as it answers. Let me focus on two questions that were raised by Huxley's essay, questions on which all of Huxley's listeners and readers seized and which are still very alive today. First, there is 
the apparent paradox seen by all-most prominently Spencer himself-that our ethical sense must have evolved and yet was supposedly something that goes against our evolutionary nature. How can this be? Either evolution leads to ethics or it does not. If it does, then Huxley is wrong. If it does not, then where does it come from? It cannot be said that Huxley dealt very well with this problem. To the printed version of the main essay he added a note beginning, "Of course, strictly speaking, social life, and the ethical process in virtue of which it advances towards perfection, are part and parcel of the general process of evolution, just as the gregarious habit of innumerable plants and animals, which has been of immense advantage to them, is so" (p. 114, n. 20). But this hardly addresses the problem, something compounded by the fact that in the years immediately before writing his essay Huxley had been speaking and writing strongly against socialism, believing it to be predicated on a utopian and morally wrong ignorance of the natural inequalities between human beings. "So long as men are men and society is society, human equality will be a dream; and the assumption that it does exist is as untrue in fact as it sets the mark of impracticability on every theory of what ought to be, which starts from it" (T. H. Huxley 1893 b, 309). Morally, he wanted us to fight the (naturally produced) beast within us, but at the same time, to acknowledge and work with the (naturally produced) differences between us.

Helpful in addressing some of the problems with his position is an unpublished fragment of a response that, even though Huxley tried writing it twice, he 
seems to have abandoned. There is enough, however, to see how Huxley thought the problem of the natural origin of the ethical sense should be tackled:

The so-called 'Ethics of Evolution' rests upon the supposition that social progress like natural history progress is dependent upon the struggle for existence. Therefore it insists that outside the charmed circle of 'natural rights' the struggle for existence shall have full play-So long as nobody directly interferes with anybody he not only may but ought to get all he can and keep all he gets. Thus 'devil take the hindmost' becomes the first great commandment-for it is no interference with your neighbour directly to get ahead of him-He may get ahead of you if he is strong enough.

I am of opinion, on the contrary, that the study of the Evolution of Ethics shews that while the feelings out of which ethical conduct has arisen, originally conduced to the advantage of each society in the struggle for existence, they to the same extent interfered with the efficiency of the struggle between the components of that society; that as soon as social organisation had got a lien on the security of life and property the struggle for existence between the component individuals was at an end; and that the relative influences of other conditions became more and more weakened as mutual help prevailed-

On the other hand the influence of education moral and intellectual, of knowledge and of in- 
stitutions, that is to say the influences of man on himself, have become supreme-In our artificial world, the struggle for enjoyment has taken the place of the struggle for existence in the state of nature. ( $\mathrm{HP} 45 \cdot 42$ )

Huxley seems to have thought that there was a struggle between groups that led to the evolution of the ethical abilities - what today we would call a process of "group selection"-and that once this got going it turned against other aspects of our evolved natures and thus we have the struggle between our two sides that prevails today. It is hardly surprising that even sympathetic commentators suggested that the old man had come full circle and was now preaching a remarkably Christian-sounding doctrine of the battle of grace and sin. Huxley, with his admitted affinity to Calvinism, would not have taken that suggestion amiss.

The second question, also raised by many-including by Leslie Stephen (1893), the first editor of the (British) Dictionary of National Biography and, incidentally, the father of the novelist Virginia Woolf-was about the ultimate source and foundation of Huxley's ethics. If it is not simply some animal force, reducible to natural selection like greed or violent feelings, then what is its status? Is it a moral claim something like mathematics, that we intuit in some fashion? Is it, in the language of the philosophers, non-natural, in the sense that it lies outside the physical world and exists eternally like a Platonic form? Huxley had written a little book on the Scottish philosopher David Hume, 
and toward the end, discussing Hume's moral philosophy, he wrote (in a passage that is intended to express Huxley's own position as much as that of Hume):

In whichever way we look at the matter, morality is based on feeling, not on reason; though reason alone is competent to trace out the effects of our actions and thereby dictate conduct. Justice is founded on the love of one's neighbour; and goodness is a kind of beauty. The moral law, like the laws of physical nature, rests in the long run upon instinctive intuitions, and is neither more nor less "innate" and "necessary" than they are. Some people cannot by any means be got to understand the first book of Euclid; but the truths of mathematics are no less necessary and binding on the great mass of mankind. Some there are who cannot feel the difference between the Sonata Appassionata, and Cherry Ripe; or between a gravestonecutter's cherub and the Apollo Belvidere; but the canons of art are none the less acknowledged. While some there may be, who, devoid of sympathy, are incapable of a sense of duty; but neither does their existence affect the foundations of morality. Such pathological deviations from true manhood are merely the halt, the lame, and the blind of the world of consciousness; and the anatomist of the mind leaves them aside, as the anatomist of the body would ignore abnormal specimens. (T. H. Huxley 1879, 207-8)

To be frank, this is not terribly helpful. If morality is just a feeling, then why is it obligatory? I like spinach. 
My wife hates it. Is there a way of deciding between our preferences? (I can appeal to the food value of spinach, but that is not quite the same thing.) If morality is like mathematics in being "necessary and binding," then how is this so? Hume and Huxley argue that society is better for having morality, but what is this to me if I can get away with things? Here too obviously we have a question left unanswered by Huxley.

As also are unanswered questions about which of our natural propensities we should fight and which we should accept. It is interesting to speculate on where Huxley would have stood with respect to our sexual desires. Socially, he was very conventional, even refusing to allow his wife to meet the novelist George Eliot because she lived openly with a man to whom she was not married. In part, this fit with his strategy (and that of other evolutionists) of being more respectable than anyone and thus showing that the science did not lead straight to sin and depravity. However, interestingly, one of his best students, Patrick Geddes, was just then coauthoring a book on sexuality, arguing that, although self-control was the best way to go, contraception was one solution to controlling family size-no small matter, given that improvements in medicine and general living had led to huge surviving family numbers (Geddes and Thompson 1889 ). Is this a case of acknowledging that certain natural propensities are good things (unlike inclinations to violence) but that morally it is permissible to curb or change their consequences (like inclinations to violence)? 


\section{From then to now}

Reaction to Huxley's essay was mixed. Some saw its real merits. Others were less impressed, a negative response compounded by the fact that the delivery of the actual lecture was less than effective, with the aged Huxley hampered by a throat cold. What can be said was that the essay did sound as a trumpet call to the dismissal of Spencerian-type evolutionary ethicizing, a dismissal in which the professional philosophersfamously, G. E. Moore in his Principia Ethica of 1903happily assisted. As it happens, T. H. Huxley's biologist grandson, Julian Huxley (older brother of the novelist Aldous Huxley), tried to revive the very position to which his grandfather was so opposed, using his opportunity (when invited to give a lecture in the same series fifty years later) to promote a progress-drenched evolutionism, leading to the ethical good, which we morally should support (J. S. Huxley 1943). This led him to endorse similar thinking by the Jesuit paleontologist Teilhard de Chardin, to whose master work The Phenomenon of Man (1955; English trans. 1959) Julian Huxley wrote an enthusiastic introduction. This time it was the Nobel Prize winner Peter Medawar who took the role of Thomas Henry. "I have read and studied The Phenomenon of Man with real distress, even with despair. Instead of wringing our hands over the Human Predicament, we should attend to those parts of it which are wholly remediable, above all to the gullibility which makes it possible for people to be taken in by such a bag of tricks as this. If it were an innocent, passive gullibility it would be excusable; but all 
too clearly, alas, it is an active willingness to be deceived" (Medawar 1961, 106). Deliberately, Medawar left ambiguous whether it was Teilhard or Julian Huxley to whom he was referring.

However-and this in itself is a major reason why Thomas Henry Huxley's essay is well worth reprinting-the past fifty years have seen major changes and advances in our thinking, both biological and philosophical, about ethics, its origins, and its nature and justifications. On the one hand, there has been intensive biological study of the empirical question that Huxley rather flubbed-namely, how do we acquire the ethical sense if a Darwinian type of evolutionary theory be true? This has led to discussion about whether people like Huxley were right in thinking that the sense comes through a kind of group-selective effect, or if it is more likely that ethical abilities come from (what today is called) individual selection, where any cooperation ultimately is a form of enlightened self-interest. You scratch my back and I will scratch yours. Suffice it to say that there are today partisans for both approaches. Some are ardent group selectionists when it comes to the ethical abilities, and others go for individual selection (often known as "selfish gene")produced mechanisms.

Incidentally, Charles Darwin did have a discussion of these issues in The Descent of Man (1871). Generally, he was much inclined to an individual-selection view of the evolutionary process and, even when it came to ethics, floated such thinking; although, then he conceded that perhaps a kind of group process might be involved. Just before Huxley's essay, the exiled Russian 
anarchist Prince Peter Kropotkin had started publishing a series of articles, later collected and published as Mutual Aid (1902), in which he argued that, far from life being governed by Spencerian struggles, a more important factor is a sense of comradeship with our fellow species members and that this, in humans, can be the basis for relatively government-free societies.

On the other hand, as much or more, there have been discussions of the kinds of philosophical issues that Huxley's discussion raises, particularly about morality and its foundations. Is evolution progressive and if it is does this produce and justify ethics? There are neo-Spencerians. One such is today's most eminent evolutionist, Edward O. Wilson. He is an ardent evolutionary progressionist, and he thinks that that justifies ethics:

Camus said that the only serious philosophical question is suicide. That is wrong even in the strict sense intended. The biologist, who is concerned with questions of physiology and evolutionary history, realizes that self-knowledge is constrained and shaped by the emotional control centers in the hypothalamus and limbic systems of the brain. These centers flood our consciousness with all the emotions-hate, love, guilt, fear, and others-that are consulted by ethical philosophers who wish to intuit the standards of good and evil. What, we are then compelled to ask, made the hypothalamus and limbic system? They evolved by natural selection. That simple biological statement must be pursued to explain ethics and ethical philosophers, 
if not epistemology and epistemologists, at all depths. (Wilson 1975, 3)

Others are not quite so sure. They look back to Thomas Henry Huxley and agree that ethical behavior involves fighting the beast within and not simply going along smoothly with the ways of evolution. This then raises the question that Huxley himself does not really answer: if ethics is not justified by evolution, then how is it justified? It seems fair to say that there is no generally accepted answer to this question. Most radically, there are those drawn to some version of the idea that perhaps recognition of our evolved nature has a corrosive effect on all attempts at ultimate justification. If morality is just a matter of biology, then is there necessarily anything over and beyond this? Perhaps the feelings about being good and about distinguishing right from wrong have no status other than that we believe them and that they serve us reasonably well as social animals. This does not mean that, because in the end there is no right and wrong, we can simply break and rape and pillage at will. Apart from the fact that others will not like us if we do this and that they will try to stop us, we are ourselves evolved beings and as such have consciences and will feel guilty if we break the moral norms. It is all a matter of psychology, but there are times when psychology can be a very powerful motivator.

\section{Envoi}

Evolution and ethics is a hot topic today, and Huxley has an important contribution to make. He died in 1895, a couple of years after his lecture was given. It 
was the last gift from a man who had been giving all of his life to his society-in education, in administration, in stimulating ideas. We today continue to benefit from what he did and thought. Truly, although Thomas Henry Huxley may not have been a great scientist, he was a great man.

\section{References}

The information in this introduction can be found in the works listed in the further reading section of this book. The Huxley Papers are housed in the college archives of Imperial College, London.

Darwin, C. 1839. Journal of Researches into the Geology and Natural History of the Various Countries Visited by HMS Beagle. London: Henry Colburn. (Modern editions often titled The Voyage of the Beagle.)

- 1859. On the Origin of Species by Means of Natural Selection, or the Preservation of Favoured Races in the Struggle for Life. London: John Murray.

- 1871 . The Descent of Man, and Selection in Relation to Sex. London: John Murray.

Geddes, P., and J. A. Thompson. 1889. The Evolution of Sex. London: W. Scott.

Huxley, J. S., ed. 1935. T. H. Huxley's Diary of the Voyage of H.M.S. Rattlesnake. London: Chatto and Windus.

- 1943. Evolutionary Ethics. Oxford: Oxford University Press.

- 1959. Introd. to The Phenomenon of Man, by Pierre Teilhard de Chardin. London: Collins. 